that we could make a machine to utilise some of the energy in the ether ; but does any one profess to know so much of that remarkable thing as to be quite certain that this is impossible? Any way, there is no doubt that to a considerable degree of accuracy inertia is a constant property of a body, and equal inertias may consequently be very reasonably considered as equality of such a very important property of two bodies, that scientific people are justified in their shortly describing the bodies as equal, which is what they usually do, and is all that they can really mean when they speak of equal quantities of iron and gold. Why, then, trouble unfortunate students with the idea that there is some huggermugger metaphysical "quantity of matter" called " mass," of which they are supposed to have a clear and definite conception distinct from this equality of inertia? Why not call it inertia when it is inertia that is meant, and drop out of use that word "mass," round which such a tissue of indistinct and obscure ideas have grown, that it is almost hopeless to separate it from them.

I hope some word more euphonious than "slug" will be found for the unit of inertia on the engineer's system. I would suggest " ert" as a term that would easily recall the quantity inertia.

Trinity College, Dublin, February Io.

\section{The Flight of Gulls in the Wake of Steamers.}

MANY persons have remarked the extraordinary power displayed by gulls of keeping pace with a steamer without any motion of their wings. A few days ago, I had a good opportunity of observing this during a voyage from Alexandria to Marseilles.

When the wind was blowing at right angles to the course of the vessel, having first gained some slight elevation, the gulls would glide downwards with expanded wings, making, during the descent, rapid progress in the same direction as the steamer. When quite near the water they would suddenly turn and face the wind, at the same time giving their bodies an upward incline, and the wind would lift them to their former elevation, after which the process would begin again. A wind blowing horizontally has the power of lifting, only because each stratum, so to speak, of air moves more rapidly than the stratum immediately below it. Consequently, as the bird rises, it has the inertia due to the fact that it has just emerged from the slower current below. Thus it may be compared to a kite, the inertia taking the place of the string. When gulls progress in this way, at right angles to the wind, the vessel does not in any way assist them, and, occasionally, when they are not following a steamer, they may be seen employing the same method.

With a head-wind they advance with even greater ease. To understand how this is possible, some investigation of the aircurrents behind the ship's stern is necessary. If small pieces of paper are thrown overboard when a strong head-wind is blowing, they are seized by a tremendous down-draught, but, some few yards astern, they suddenly dart up again. In fact, as the vessel moves onward, the air rushes down to fill the vacuum, then rebounds off the surface of the sea, and forms an up-current. Placing himself in this up-current, the gull is lifted as if he were no heavier than a scrap of paper, then he glides downward and onward. But as the vessel moves on, the up-current advances, or, strictly speaking, the point at which the up-current is formed. At the end of his descent the gull finds himself in this, is again lifted, and the process is repeated.

When the wind was not a due head-wind, but struck the vessel at a slight angle, now and then a gull would be seen apparently hovering motionless over the stern, of course really gliding onward with the vessel. Though I cannot speak with confidence of the explanation of this, the most wonderful of the methods employed, I wish to put forward what seems the probable explanation. The wind striking against the side of the vessel is deflected upwards, and it is this up-current which buoys up the gull as he floats over the stern. Though it may appear that his progress is perfectly uniform, I think it will be found that in advancing he descends slightly, that he often loses ground for a time, and that while losing ground he ascends. Thus the method in this case is really the same as in that last described. Unfortunately, I was not able to prove the existence of this up-current about 20 feet above the stern of the vessel. But there is good evidence of it in the fact that the gull remains suspended there without a motion of his wings. Without an No. I 426 , vOL. 55$]$ up-current this would be an impossibility. It is to be hoped that good observers will give their attention to these very interesting phenomena.

Haileybury, February 8 F. W. Headley.

\section{Two Unfelt Earthquakes}

ON February 7, commencing at about 8 a.m., G.M.T., an unusually large, but, at the same time, unfelt earthquake was recorded in the Isle of Wight. The preliminary tremors, which include three well-defined maxima, extended over twenty-six minutes. After these came two periods of heavy movement, each extending over fifteen or twenty minutes. The duration of the whole disturbance was about one and one-half hours. It was Japanese in character, and because it was recorded in Tochia by Dr. G. Grablovitz, and at the same time was so marked in ampli. tude and duration, it is not unlikely that it disturbed the entire surface of the globe.

On the I 3 th there was a comparatively small disturbance, with preliminary tremors of three or four minutes, at about to a.m. I should be pleased to learn whether these earthquakes were recorded by bifilar pendulums in Edinburgh or Eirmingham, or at any of our magnetic observatories.

Shide, Newport, I.W., February 18. JOHN MiLNE.

\section{FOUNDATIONS OF CORAL ATOLLS.}

THE most regrettable failure of the boring lately attempted in the coral atoll of Funafuti has left us as wise as we were as to the actual structure of these formations; but the surveys carried on by H.M.S. Penguin, both at $F$ unafuti and in the regions round about, have afforded information which, I think, is of value in elucidating some of the problems to be solved, and which has certainly strengthened some of my own views on the subject.

Funafuti, it may be mentioned, was selected for investigation as being one of a great Pacific group of atolls, which must have a common great cause for the formation of their necessary foundations, and for their development; groups which had a great share in causing $\mathrm{Mr}$. Darwin to conclude, from the lack of other explanation of banks in large numbers at a proper depth for the growth of an atoll, that subsidence on a large scale was the predominant agent in their production ("Coral Reefs," 2nd ed., pp. I I 8 , I19; 3rd ed., pp. I20, 121.)

Firstly, the sounding carried on by the Penguin round Funafuti and between separate islands of the Ellice Group, show incontestably that each atoll is situated on a separate mound, rising from a more or less even bottom of great depth below the surface. This proves that there has never been anything of the nature of a range of continental land which has gradually sunk beneath the waves. Each atoll, if it has sunk, has subsided independently, with its own isolated volcanic peak.

Secondly, the Penguin, while searching the seas some 250 miles to the south-westward of the Ellice Islands for several reported dangers to navigation, explored four banks, all of submerged atoll form, lying near one another.

The remarkable thing about these banks is the absolute uniformity of the depth of water over their areas, ins:de the low rim of growing coral which encircles their edges in various degree. This depth is 24 to 26 fathoms. The banks are large : one is 22 miles by 10 ; another is 18 miles by 9 ; the third is 8 by 7 ; and the fourth 4 by 3. The plan of one of them is given on the next page as an example.

Another bank, investigated a few years ago by H.M.S Waterwitch, and lying 400 miles to the eastward, presents similar characteristics, and the same depth over its central area. All these banks are situated in a region exposed to the same conditions of wind and sea.

What causes this remarkable similarity of depth and this extraordinarily even surface over these large banks? Is 